\title{
Protein binding of progesterone in rat plasma
}

\author{
D. L. Willcox and N. W. Bruce \\ Raine Centre for the Study of Perinatal and Developmental Biology, Department of Anatomy and \\ Human Biology, University of Western Australia, Nedlands, Western Australia 6009, Australia
}

\begin{abstract}
Summary. The plasma of female rats contained progesterone-binding proteins similar to those found in luteal extracts and plasma of cows and sheep. These proteins were not ovarian in origin. The progesterone-binding activity of ovarian venous and arterial plasma of Day-16-pregnant rats and arterial plasma of rats in dioestrus was resolvable by hydroxylapatite chromatography into three components. The first component was identified as corticosteroid-binding globulin because it bound corticosterone and cortisol as well as progesterone and was not adsorbed to hydroxylapatite. The second and third components were eluted from hydroxylapatite at phosphate ionic strengths of $40 \mathrm{mM}$ and $150 \mathrm{mM}$ and bound progesterone with $99 \%$ less affinity. Competition experiments using the second component showed that it bound progesterone specifically. The progesterone-binding components were present in arterial plasma collected from rats which had been ovariectomized 5 days previously and in animals in which circulating concentrations of progesterone had been maintained by subcutaneous injections of progesterone for 6 days after ovariectomy.
\end{abstract}

\section{Introduction}

Most of the progesterone circulating in the blood of mammals is protein-bound, either unsaturably with low affinity to albumin or saturably with greater affinity to proteins such as glucocorticoid binding globulin (CBG). However, it is possible that progesterone is bound to other proteins because during human pregnancy as much as $40 \%$ of the circulating hormone is bound to 'unassigned proteins' which are neither albumin nor CBG (Rosenthal, Slaunwhite \& Sandberg, 1969). Furthermore the plasma and corpus luteum of cows and sheep contain two proteins which bind progesterone with affinities between that of albumin and CBG (Willcox, 1979; Willcox \& Thorburn, 1981; Willcox, 1983). The proteins are distinguishable on sucrose gradients and on columns of hydroxylapatite from other circulating proteins which bind steroids. Pregnenolone, $5 \alpha-$ pregnanedione, deoxycorticosterone and $17 \alpha$-hydroxyprogesterone compete with progesterone for binding to ruminant proteins, whereas oestrogens and cortisol do not. The function of these proteins is unknown but their presence in the ovary as well as in blood is consistent with a proteinmediated mechanism for secretion of progesterone in ruminants (Gemmell, Stacy \& Thorburn, 1974; Parry, Willcox \& Thorburn, 1981; Willcox \& Alison, 1982).

This study set out to establish whether the plasma of female rats contains progesterone-binding proteins similar to those found in ruminants, and to determine whether these proteins were ovarian in origin. Preliminary results have been reported (Willcox \& Bruce, 1981). 


\section{Materials and Methods}

Chemicals. All chemicals were Analar grade. Crystalline steroids, fluorescamine, and activated charcoal were purchased from Sigma Chemical Co. (Sydney). Hydroxylapatite (HTP grade) was obtained from Biorad Laboratories (Sydney), and Sephadex resins and dextran T-70 from Pharmacia (Sydney). Amersham International (Amersham, U.K.) supplied $\left[1,2,6,7-{ }^{3} \mathrm{H}\right]$ progesterone (sp. act. $80-100 \mathrm{Ci} / \mathrm{mol}),\left[4-{ }^{14} \mathrm{C}\right]$ cortisol (sp. act. $\left.55 \mathrm{mCi} / \mathrm{mmol}\right)$ and $\left[1,2,6,7-{ }^{3} \mathrm{H}\right]$ corticosterone (sp. act. $80-105 \mathrm{Ci} / \mathrm{mmol}$ ).

Animals. Mature, nulliparous albino Wistar rats were used. They were kept at a mean temperature of $19^{\circ} \mathrm{C}$ (range $17-23^{\circ} \mathrm{C}$ ), relative humidity of $70 \%(65-75 \%)$ and in $14 \mathrm{~h} \mathrm{light} /$ day $(07: 00-21: 00 \mathrm{~h})$. Food and water were freely available. Vaginal smears were taken at $09: 00-10: 00$ $\mathrm{h}$ to detect the stage of the oestrous cycle or mating. The morning that spermatozoa were found in a vaginal smear was called Day 1 of gestation.

Collection of plasma. Ovarian venous blood was collected from rats anaesthetized with pentobarbitone sodium as described previously (Bruce \& Dimmitt, 1977; Bruce, Meyer \& Dimmitt, 1980). Up to $60 \mathrm{ml}$ blood was collected from individual rats on Day 16 of pregnancy over $3 \frac{1}{2} \mathrm{~h}$ by continuous replacement of the ovarian venous blood with blood freshly taken from other Day-16pregnant rats. Replacement blood was administered, via a cannula inserted into the left common carotid artery, at a rate $(\sim 0.3 \mathrm{ml} / \mathrm{min})$ which maintained blood volume to within $5 \%$ of normal. Arterial blood was obtained from pregnant, ovariectomized and non-pregnant rats anaesthetized with ether. Their aortas were exposed by a ventral midline incision and blood was withdrawn into a heparinized syringe. Two groups of non-pregnant rats were anaesthetized with ether and ovariectomized; one group (progesterone-treated rats) received once-daily s.c. injections of $20 \mathrm{mg}$ progesterone in $0.4 \mathrm{ml}$ peanut oil (Rampire Laboratories, Perth) for 6 days.

Column chromatography. Plasma, in some cases equilibrated with radioactive steroids, was applied to columns of hydroxylapatite and hydrated Sephadex G-25 $(1: 2, \mathrm{v} / \mathrm{v})$ hereafter referred to simply as hydroxylapatite. The columns were developed in steps of $1.5-2$ column volumes of potassium phosphate buffer, $\mathrm{pH} 6 \cdot 8$, of increasing ionic strength.

Progesterone radioimmunoassay. The procedures used were similar to those of McNatty, Gibb, Dobson, Thurley \& Findlay (1981) and used the same antiserum (Wallaceville-26). Samples were extracted in duplicate into redistilled petroleum ether with $75.5 \pm 2.6 \%$ efficiency (mean \pm s.e.m. of 4 assays). Solvent blanks were routinely equivalent to $<5 \mathrm{pg} / \mathrm{ml}$ and the limit of sensitivity in the assay was $25 \mathrm{pg} /$ tube. Isolation of progesterone by chromatography on Sephadex LH-20 indicated that further purification of the organic extracts of plasma and column fractions before assay was unnecessary. The recovery of progesterone after LH-20 chromatography was $68 \pm 5 \%(n=10)$ and the coefficient of variation between samples assayed directly or after chromatography was $16 \%$ $(n=10)$. The intra- and inter-assay coefficients of variation of the steroid assays $(n=4)$ were $7 \%$ and $11 \%$, respectively.

Steroid binding. The equilibrium association constant $\left(K_{\mathrm{a}}\right)$ and binding capacity for progesterone-binding and the relative affinity for other steroids were determined by multiple equilibrium dialysis as described previously (Willcox \& Thorburn, 1981). The concentrations in plasma and column fractions of protein and endogenous progesterone remaining after charcoal treatment were determined by fluorometry (Böhlen, Stein, Dairman \& Udenfriend, 1973) and by radioimmunoassay, respectively, and were included in the analysis of the data according to Scatchard (1949). The experimentally determined curve was resolved into its high- and low-affinity binding components (Chamness \& McGuire, 1975) and the slope of the high-affinity line was obtained by least-squares regression analysis (Snedecor \& Cochran, 1980).

\section{Progesterone binding in rat plasma}

\section{Results}

The presence of binding activities specific for progesterone in ovarian venous plasma and arterial plasma from pregnant rats, and in arterial plasma from rats in dioestrus, was investigated. 


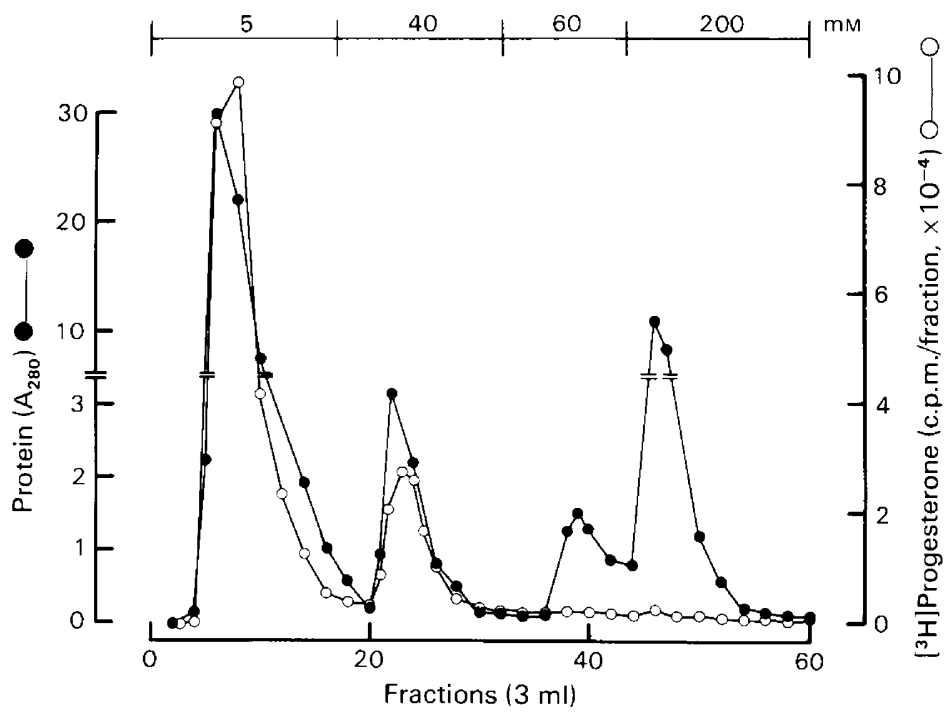

Text-fig. 1. Fractionation of rat ovarian venous plasma on hydroxylapatite. A Day-16-pregnant rat was anaesthetized and prepared surgically for collection of ovarian venous blood, $25 \mathrm{ml}$ of which was collected within $85 \mathrm{~min}$. Ovarian venous plasma $(12 \cdot 1 \mathrm{ml})$ was then incubated with [ ${ }^{3} \mathrm{H}$ ]progesterone $(0.5 \mu \mathrm{Ci}, 5 \mathrm{pmol})$ for $90 \mathrm{~min}$ on ice, and $11.6 \mathrm{ml}$ were applied to a column of hydroxylapatite $\left(1.8\right.$ (i.d.) $\times 9 \mathrm{~cm}$ ). The column was developed at $4^{\circ} \mathrm{C}$ in steps with potassium phosphate buffer, $\mathrm{pH} 6 \cdot 8$, and fractions of $3 \mathrm{ml}$ were collected at $\leqslant 10 \mathrm{ml} / \mathrm{h}$.

Freshly collected ovarian plasma from Day-16-pregnant rats was incubated with radioactive progesterone and applied to a column of hydroxylapatite (Text-fig. 1). The added progesterone was recovered principally at $5 \mathrm{~mm}$-phosphate with unretarded material but $16.5 \%$ was retained by the adsorbed proteins that were eluted at $40 \mathrm{~mm}$-phosphate. When ovarian venous or arterial plasma from pregnant or dioestrous rats was equilibrated before chromatography with radioactive cortisol or corticosterone, as well as radioactive progesterone (Text-fig. 2), the distribution of eluted progesterone was unchanged and the glucocorticoids were recovered entirely with the unadsorbed material at 5 mm-phosphate. Gradient elution did not provide such discrete peaks of protein as did the more extensive form of step elution shown in Text-fig. 2, but showed that proteins did not elute between 5 and 40 mM-phosphate (not shown).

The presence of albumin and CBG among the proteins of Peak I from the hydroxylapatite column was investigated by measuring the binding of progesterone, corticosterone, and oestradiol$17 \beta$ by equilibrium dialysis before and after heating of Peak I at $60^{\circ} \mathrm{C}$ for $20 \mathrm{~min}$. Such heating reduces the binding of rat $\mathrm{CBG}$ for progesterone and corticosterone but does not affect albumin's affinity for all three steroids (Westphal, 1970). At steroid concentrations of $1 \times 10^{-10} \mathrm{M}$ and $1 \times$ $10^{-8} \mathrm{M}$, binding of progesterone and corticosterone by heated Peak I declined to $60 \%$ and $40 \%$, respectively, of the unheated values. In contrast, binding of oestradiol-17 $\beta$ was greatest after heat treatment and at a steroid concentration of $1 \times 10^{-5} \mathrm{M}$ was still $27 \%$ of that obtained at $1 \times 10^{-10}$ M-oestradiol-17 $\beta$.

The progesterone-binding activities of the peaks of protein obtained by fractionation of ovarian venous plasma on hydroxylapatite were measured by equilibrium dialysis (Table 1). Peak I, recovered at $5 \mathrm{~mm}$-phosphate, bound progesterone with an association constant of the order of $10^{8}$ $1 / \mathrm{mol}$, which was similar to that of unfractionated plasma. Peaks II and V, eluted by $40 \mathrm{~mm}$ - and 150 mM-phosphate, respectively, bound progesterone less avidly; none of the other peaks from the column bound progesterone, with high or low affinity. The binding activity associated with Peak V was labile in dilute aqueous solution and difficult to quantify; nonetheless, it appeared to bind less hormone per gram of protein than did peak I or peak II. There were no obvious differences between 


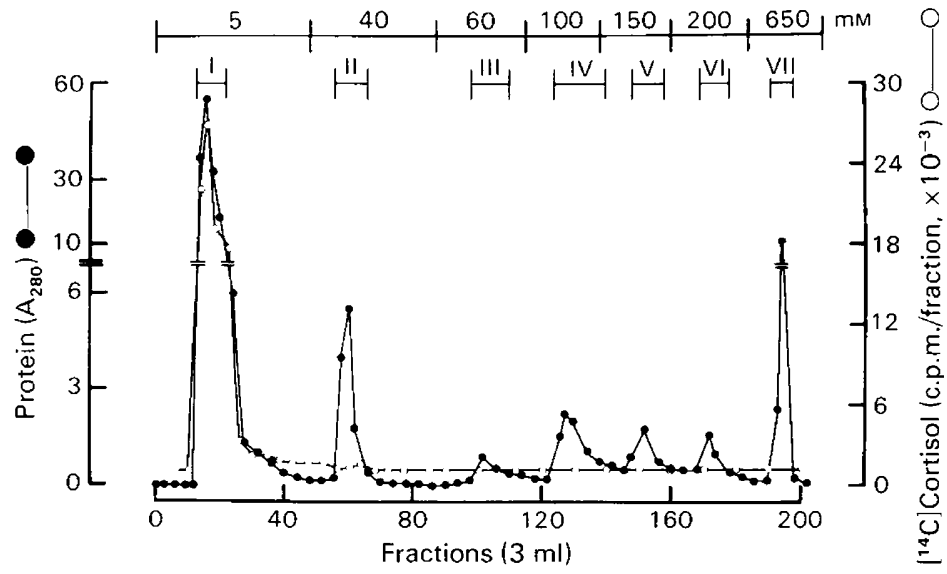

Text-fig. 2. Fractionation of rat ovarian venous plasma on hydroxylapatite. Ovarian venous blood $(64 \mathrm{ml})$ was collected over $3.5 \mathrm{~h}$ from a Day-16-pregnant rat and $25 \mathrm{ml}$ plasma were then incubated with $\left[{ }^{14} \mathrm{C}\right]$ cortisol $(1.5 \mu \mathrm{Ci}, 27 \mathrm{nmol})$ for $80 \mathrm{~min}$ on ice, and $24.7 \mathrm{ml}$ were applied to a column of hydroxylapatite $(1.7$ (i.d.) $\times 15 \mathrm{~cm})$. The column was developed at $4^{\circ} \mathrm{C}$ in steps with potassium phosphate buffer, $\mathrm{pH} 6.8$; fractions of $3 \mathrm{ml}$ were collected at flow rates of $12-30 \mathrm{ml} / \mathrm{h}$ and grouped into 7 pools (I-VII).

Table 1. Equilibrium dialysis and Scatchard analysis of the progesterone-binding activity of rat plasma and the pools of protein obtained from it by fractionation on hydroxylapatite

\begin{tabular}{|c|c|c|}
\hline Source of plasma binding activity* & $K_{\mathrm{a}}\left(1 / \mathrm{mol} \times 10^{-6}\right)$ & $\begin{array}{l}\text { Binding capacity } \\
\text { (pmol/mg protein) }\end{array}$ \\
\hline \multicolumn{3}{|l|}{ Day-16-pregnant rats } \\
\hline Unfractionated ovarian venous plasma & 577,930 & $556 \cdot 0,580 \cdot 9$ \\
\hline Peak I (5 mM): Ovarian venous & 560 & $108 \cdot 5$ \\
\hline Arterial & 462 & $120 \cdot 6$ \\
\hline Peak II $(40 \mathrm{~mm})$ : Ovarian venous & $5 \cdot 83,11 \cdot 15$ & $130 \cdot 6,118 \cdot 6$ \\
\hline Arterial & $5 \cdot 32$ & 38.4 \\
\hline Peak III (60 mM): Ovarian venous & \multicolumn{2}{|c|}{ No specific binding } \\
\hline Peak IV (100 mM): Ovarian venous & \multirow{2}{*}{\multicolumn{2}{|c|}{$\begin{array}{l}\text { No specific binding } \\
\text { No specific binding }\end{array}$}} \\
\hline Arterial & & \\
\hline Peak V (150 mM): Ovarian venous & 2.96 & 3.05 \\
\hline Peak VI $(200 \mathrm{mM})$ : Ovarian venous & \multicolumn{2}{|c|}{ No specific binding } \\
\hline Arterial & \multicolumn{2}{|c|}{ No specific binding } \\
\hline Peak VII $(650 \mathrm{~mm})$ : Ovarian venous & \multicolumn{2}{|c|}{ No specific binding } \\
\hline \multicolumn{3}{|l|}{ Dioestrous rats } \\
\hline Unfractionated arterial plasma & 688,742 & 525,618 \\
\hline Peak I (5 mM): Arterial & 608 & $124 \cdot 6$ \\
\hline Peak II (40 mM): Arterial & 2.59 & $76 \cdot 2$ \\
\hline Peak V (40-650 mM): Arterial & 3.91 & $2 \cdot 9$ \\
\hline \multicolumn{3}{|l|}{ Ovariectomized rats } \\
\hline Unfractionated arterial plasma & 371 & $515 \cdot 7$ \\
\hline Peak I (5 mM): Arterial & 608 & $124 \cdot 6$ \\
\hline Peak II (40 mM): Arterial & 5.01 & $131 \cdot 3$ \\
\hline Peak V $(40-650 \mathrm{mM})$ : Arterial & $6 \cdot 70$ & $0 \cdot 6$ \\
\hline
\end{tabular}

$K_{\mathrm{a}}=$ equilibrium association constant for progesterone.

* The phosphate concentration at which each protein peak was eluted from the column is shown in parentheses (see Text-figs $2 \& 3$ ). 
the binding activities for progesterone of unfractionated ovarian venous plasma and arterial plasma, obtained from pregnant or non-pregnant rats. Similar binding activities were found also for peaks II and V isolated from these plasmas, except that in 4 separate experiments the measured binding capacity for hormone of peak II from ovarian venous plasma exceeded by $1 \cdot 5$ - to 4 -fold that of peak II from arterial plasma (Table 1).

The ability of other steroids to compete with progesterone for binding to the peak II proteins from the hydroxylapatite column was assessed by dialysing various amounts of different steroids and a constant amount of $\left[{ }^{3} \mathrm{H}\right]$ progesterone against $1.0 \mathrm{ml}$ aliquants of the protein solution (Table 2). No steroid was bound with greater affinity than progesterone, and those steroids with related structures such as $20 \alpha$-dihydroprogesterone, deoxycorticosterone, testosterone and pregnenolone cross-reacted most effectively with progesterone. Oestrogens, glucocorticoids and cholesterol did not cross-react significantly.

Table 2. Relative affinities for other steroids of the progesterone-binding component in peak II obtained by hydroxylapatite column chromatography of ovarian venous plasma from 16-day-pregnant rats

\begin{tabular}{|c|c|c|c|c|}
\hline \multirow[b]{2}{*}{ Steroid } & \multicolumn{4}{|c|}{$\%$ Cross-reaction* } \\
\hline & Exp. 1 & Exp. 2 & Exp. 3 & Mean \\
\hline Progesterone & 100 & 100 & 100 & 100 \\
\hline $20 \alpha$-Dihydroprogesterone $\dagger$ & $62 \cdot 3$ & & $59 \cdot 4$ & 61 \\
\hline Deoxycorticosterone $\ddagger$ & $57 \cdot 8$ & & $57 \cdot 2$ & 58 \\
\hline $17 \alpha-$ Hydroxyprogesterone $\S$ & $44 \cdot 6$ & & & 45 \\
\hline Testosterone & $25 \cdot 1$ & $33 \cdot 4$ & & 29 \\
\hline Pregnenolone & $26 \cdot 6$ & $23 \cdot 6$ & & 25 \\
\hline $5 \alpha-$ Pregnanedione & $19 \cdot 8$ & & $11 \cdot 8$ & 16 \\
\hline $17 \alpha-$ Hydroxypregnenolone $\mathbb{T}$ & & & 6.6 & 7 \\
\hline Dihydrotestosterone & & & $2 \cdot 4$ & 2 \\
\hline Androstenedione & 0.8 & & $1 \cdot 2$ & 1 . \\
\hline Oestradiol-17 $7 \beta$ & 0.45 & 0.25 & & 0.4 \\
\hline Oestrone & & & 0.01 & 0.01 \\
\hline Corticosterone & & 0 & 0 & 0 \\
\hline Cortisol $\|$ & 0 & 0 & & 0 \\
\hline Cholesterol & 0 & & & 0 \\
\hline
\end{tabular}

\footnotetext{
* Cross-reaction $=$ (amount of progesterone causing 50\% decrease in binding)/ (amount of other steroid causing 50\% decrease in binding).

$+\Delta^{4}$-Pregnen-20 $\alpha$-ol-3-one.

¥ Pregnen-21-ol-3,20-dione.

$\S \Delta^{4}$-Pregnen-17 $\alpha$-ol-3,20-dione.

I $3 \beta, 17 \alpha$-Dihydroxy- $\Delta^{5}$-pregnen-20-one.

|| 4-Pregnene-11 $\beta, 17 \alpha, 21$-triol-3,20-dione.
}

Is the ovary the source of progesterone binding protein?

Having established that the plasma of female rats contained two binding components, one (at least) of which was specific for progesterone, the possibility was investigated that the binding proteins were synthesized and released from the ovary. Eleven rats were ovariectomized and divided into 2 groups. After 5 days, arterial plasma was obtained from Group 1 rats $(\mathrm{N}=6)$, pooled, equilibrated with tritiated progesterone and fractionated on hydroxylapatite. Radioactive progesterone was recovered with the proteins eluted at $5 \mathrm{~mm}$-and $40 \mathrm{~mm}$-phosphate (Text-fig. 3). Equilibrium dialysis showed that the progesterone-binding properties of unfractionated and fractionated plasma from these ovariectomized rats were unchanged from those of intact rats (Table 1). 


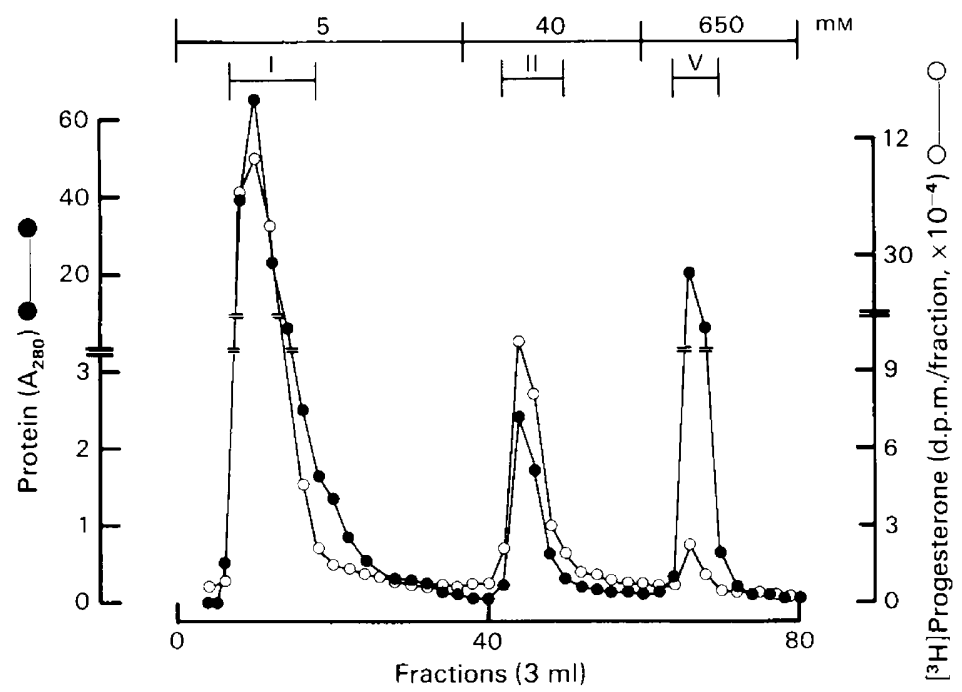

Text-fig. 3. Fractionation on hydroxylapatite of arterial plasma from rats ovariectomized 6 days previously. Six rats were ovariectomized (mean weights $198 \cdot 7 \pm 4.6 \mathrm{~g}$ and $202.8 \pm 3.8 \mathrm{~g}$ on Days 0 and 5, respectively) and their arterial blood collected. Radioactive progesterone ( $2 \cdot 4$ $\mu \mathrm{Ci}, 25 \mathrm{pmol}$ ) was then added to $14.5 \mathrm{ml}$ pooled plasma, equilibrated on ice for $80 \mathrm{~min}$, and applied to a column of hydroxylapatite $\left(2.0\right.$ (i.d.) $\times 7.7 \mathrm{~cm}$ ). The column was developed at $4^{\circ} \mathrm{C}$ in steps with potassium phosphate buffer, $\mathrm{pH} 6.8$; fractions of $3 \mathrm{ml}$ were collected at a flow rate of $24 \mathrm{ml} / \mathrm{h}$.

The rats in Group $2(\mathrm{~N}=5)$ were given daily injections of progesterone in peanut oil. On the 6th day, their arterial plasma concentration of progesterone was $608 \pm 63(\mathrm{~N}=5) \mathrm{ng} / \mathrm{ml}$ compared to $16.5 \pm 2.5(\mathrm{~N}=6) \mathrm{ng} / \mathrm{ml}$ for Group 1. The arterial plasmas of Group-2 rats were pooled, equilibrated with $\left[{ }^{3} \mathrm{H}\right]$ progesterone, and applied to a column of hydroxylapatite. Tritiated progesterone added to the plasma of the rats in Group 2 was recovered after chromatography with the proteins eluted by $5 \mathrm{~mm}$ - and $40 \mathrm{~mm}$-phosphate, but not with proteins eluted above $40 \mathrm{~mm}$ phosphate (not shown). In this case, the pools of protein obtained from the hydroxylapatite column were not subjected to equilibrium dialysis.

\section{Discussion}

Our results show that in addition to $\mathrm{CBG}$ and albumin the plasma of female rats contains two binding proteins for progesterone analogous to those found in luteal extracts and plasma from cows and sheep (Willcox, 1979, 1983; Willcox \& Thorburn, 1981). The rat proteins were recovered from columns of hydroxylapatite at $40 \mathrm{~mm}$-phosphate (peak II) and $150 \mathrm{~mm}$-phosphate (peak V) compared to 40 and $100 \mathrm{~mm}$-phosphate, respectively, for the ruminant proteins.

We identified three progesterone-binding activities in rat plasma by chromatography and equilibrium dialysis of the protein peaks obtained. Addition of radioactive progesterone and cortisol or corticosterone to plasma before chromatography revealed a binding activity for all three steroids in peak $\mathrm{I}$, which consisted of those proteins (including CBG and albumin) and small molecular weight solutes not adsorbed to hydroxylapatite, and a binding activity for progesterone only in peak II (Text-figs 1 \& 2). Progesterone apparently dissociated during chromatography since equilibrium dialysis of all 7 protein peaks from the column revealed the presence of a third progesterone-binding activity (peak V) eluted at $150 \mathrm{~mm}$-phosphate (Table 1). Scatchard analysis of 
these steroid-binding activities was consistent with the presence of a single high-affinity binding component in each peak.

CBG and albumin are present in rat plasma and bind progesterone (Seal \& Doe, 1965; Westphal, 1970). However, a number of factors indicate that the progesterone-binding activities associated with peaks II and V are different from CBG and albumin. Firstly, the association constants of the former for progesterone at $4^{\circ} \mathrm{C}$ were of the order of $10^{6} \mathrm{l} / \mathrm{mol}$, which is between that reported for CBG $\left(10^{8} 1 / \mathrm{mol}\right)$ and albumin $\left(10^{4} 1 / \mathrm{mol}\right)$. Secondly, albumin comprises about half of the protein in plasma whereas only $6-12 \%$ of the protein in ovarian venous and arterial plasma was recovered in peaks II and $\mathrm{V}$ after chromatography (Text-fig. 2). Thirdly, albumin and CBG are not adsorbed to hydroxylapatite and bind glucocorticoids as well as progesterone (Muldoon \& Westphal, 1967). Fourthly, the binding of progesterone and corticosterone by CBG in peak I was reduced by heating whereas albumin in peak I bound progesterone, corticosterone and oestradiol$17 \beta$ unsaturably over a $10^{5} \mathrm{M}$ concentration range. Therefore, the progesterone-binding activity in peak I from the hydroxylapatite column was due probably to CBG and albumin since added cortisol and corticosterone were recovered entirely with this peak (Text-fig. 1) and its equilibrium association constant for the high-affinity binding of progesterone $\left(\mathrm{Ka}=4 \cdot 6-6 \cdot 1 \times 10^{8} \mathrm{l} / \mathrm{mol}\right.$, Table 1) was similar to that reported for rat CBG $\left(5 \times 10^{8} \mathrm{l} / \mathrm{mol}\right.$; Westphal, 1970).

The steroid-binding protein isolated from rat plasma on hydroxylapatite at $40 \mathrm{~mm}$-phosphate (peak II in Text-figs 1 \& 2) bound progesterone preferentially in the presence of other steroids, and steroids with structures that closely resembled progesterone competed most effectively with it for binding (Table 2). For example, 20 $\alpha$-dihydroprogesterone, the second most abundant progestagen in rat plasma after progesterone, deoxycorticosterone and 17 $\alpha$-hydroxyprogesterone were strong competitors whereas testosterone, pregnenolone and $5 \alpha$-pregnanedione competed less well. Furthermore, oestrogens and glucocorticoids did not compete with progesterone for binding. A similar pattern of relative steroid affinities was observed for the progesterone-binding proteins of the bovine corpus luteum, except that pregnenolone and $5 \alpha$-pregnanedione were bound more strongly (Willcox \& Thorburn, 1981).

The capacity of the binding protein in peak $\mathrm{V}$ after dialysis for $24 \mathrm{~h}$ was much less than that of the binding protein in peak II. However, the affinities and capacities of the progesterone-binding activities in both peaks were variable (Table 1), and differences in these values between ovarian and arterial plasmas, or between pregnant and non-pregnant rats, were not discernible. The binding proteins may have lost activity during chromatography and prolonged dialysis in diluted form. The steroid-binding properties of the proteins found in ruminants were unaffected by the presence or absence of sulphydryl groups or protease inhibitors, but were reduced by freezing and thawing, freeze-drying or gel filtration in the absence of progesterone (Willcox, 1979; Willcox \& Thorburn, 1981). It is therefore difficult to extrapolate the binding capacities of the rat proteins determined by equilibrium dialysis in dilute solution to the amount of hormone that they may bind in the blood of living rats.

The biological function of these binding proteins is presently unknown but they may be involved in secretion of progesterone from the ovary and/or in the transport of the hormone in blood. It has been suggested that the ruminant proteins are taken up by, or synthesized in, the corpus luteum and are then secreted into blood bound to progesterone, where they act as carrier proteins for the hormone together with CBG and albumin (Willcox, 1979; Sawyer, Abel, McClellan, Schmitz \& Niswender, 1979; Willcox \& Alison, 1982; Willcox, Parry \& Morris, 1983). Measurement of an arterial-venous difference in the concentration of binding proteins across the ovary that such a mechanism implies awaits the development of a direct assay for the proteins. We found that the binding proteins were present in arterial plasma of ovariectomized, dioestrous, Day16-pregnant and progesterone-supplemented rats, indicating that the synthesis of binding proteins from an organ other than the ovary was independent of the plasma concentrations of progesterone over a 60 -fold range. Furthermore, their synthesis is not specific to pregnancy, since they were found in the plasma of dioestrous as well as pregnant rats. 
Our results suggest that rat luteal cells do not synthesize the progesterone-binding proteins found in plasma unless they have half-lives in blood of the order of weeks rather than days. If this is the case, their plasma concentration would have dropped insufficiently 5-6 days following ovariectomy for us to have detected it. Half-lives of this order for these proteins are possible since the half-life of rat albumin is 2.67 days (Schreiber, Urban, Zahringer, Reutter \& Frosch, 1971).

It has not been determined whether the rat corpus luteum contains progesterone-binding proteins analogous to those found in the corpora lutea of ruminants. When bovine luteal slices were incubated in vitro secretion of progesterone was enhanced by the addition of serum proteins to the medium (Condon \& Pate, 1981) and, in another study, binding proteins were secreted concomitantly with progesterone (Willcox \& Alison, 1982). Therefore, it is possible that rat luteal cells do not synthesize the binding proteins but take them up from blood and secrete them bound to progesterone as a macromolecular complex. These questions, and the structural relatedness of the progesterone-binding proteins to each other and to other circulating proteins, remain to be elucidated.

We thank the King Edward Memorial Hospital Research Foundation and the Australian Research Grants Scheme for financial support, Dr K. P. McNatty, Wallaceville Animal Research Centre, New Zealand, for antiserum to progesterone and Mrs P. Williamson for typing the manuscript. D.L.W. is a Raine Research Fellow.

\section{References}

Böhlen, P., Stein, S., Dairman, W. \& Udenfriend, S. (1973) Fluorimetric assay of proteins in the nanogram range. Archs Biochem. Biophys. 155, 213-230.

Bruce, N.W. \& Dimmitt, S.B. (1977) Ovarian venous blood flow in non-pregnant and pregnant rats. $J$. Endocr. 72, 127-133.

Bruce, N.W., Meyer, G.T. \& Dimmitt, S.B. (1980) Progesterone secretion and ovarian blood flow in the pregnant rat. $J$. Endocr. 85, 327-330.

Chamness, G.C. \& McGuire, W.L. (1975) Scatchard plots: common errors in correction and interpretation. Steroids 26, 528-542.

Condon, W.A. \& Pate, J.L. (1981) Influence of serum and its lipoprotein fractions on progesterone synthesis and secretion by bovine luteal tissue in vitro. Biol. Reprod. 25, 950-957.

Gemmell, R.T., Stacy, B.D. \& Thorburn, G.D. (1974) Ultrastructural study of secretory granules in the corpus luteum of the sheep during the estrous cycle. Biol. Reprod. 11, 447-462.

McNatty, K.P., Gibb, M., Dobson, C., Thurley, D.C. \& Findlay, J.K. (1981) Changes in the concentration of gonadotrophic and steroidal hormones in the antral fluid of ovarian follicles throughout the oestrous cycle of the sheep. Aust. J. biol. Sci. 34, 67-80.

Muldoon, T.G. \& Westphal, U. (1967) Steroid-protein interactions. $\mathrm{XV}$. Isolation and characterization of corticosteroid-binding globulin from human plasma. J. biol. Chem. 242, 5636-5643.

Parry, D.M., Willcox, D.L. \& Thorburn, G.D. (1981) Ultrastructural and cytochemical study of the bovine corpus luteum. J. Reprod. Fert. 60, 349-357.

Rosenthal, H.E., Slaunwhite, W.R., Jr \& Sandberg, A.A. (1969) Transcortin: a corticosteroid-binding protein of plasma. X. Cortisol and progesterone interplay and unbound levels of these steroids in pregnancy. J. clin. Endocr. Metab. 29, 352-367.
Sawyer, H.R., Abel, J.H., Jr, McClellan, M.C., Schmitz, M. \& Niswender, G.D. (1979) Secretory granules and progesterone secretion by ovine corpora lutea in vitro. Endocrinology 104, 476-486.

Scatchard, G. (1949) The attractions of proteins for small molecules and ions. Ann. N.Y. Acad. Sci. 57, 660-672.

Schreiber, G., Urban, J., Zahringer, J., Reutter, W. \& Frosch, U. (1971) The secretion of serum protein and the synthesis of albumin and total protein in regenerating rat liver. J. biol. Chem. 246, 4531-4538.

Seal, U.S. \& Doe, R.P. (1965) Vertebrate distribution of corticosteroid-binding globulin and some endocrine effects on concentration. Steroids 5, 827-841.

Snedecor, G.W. \& Cochran, W.G. (1980) Statistical Methods, 7th edn, pp. 149-174. Iowa State University Press, Ames.

Westphal, U. (1970) Steroid-protein interactions. In Monographs of Endocrinology, vol. 4, pp. 237-293; 315-355. Ed. F. Gross. Springer-Verlag, Berlin.

Willcox, D.L. (1979) Hormone secretion in the corpus luteum. D. Phil. thesis, University of Oxford.

Willcox, D.L. (1983) Two binding proteins for progesterone in the bovine corpus luteum. Biol. Reprod. (in press).

Willcox, D.L. \& Alison, M.R. (1982) Release of protein which binds progesterone from the bovine corpus luteum. $J$. Endocr. 92, 51-61.

Willcox, D.L. \& Bruce, N.W. (1981) Protein binding of progesterone in rat plasma. Proc. Aust. Soc. Reprod. Biol. 13, 78, Abstr.

Willcox, D.L. \& Thorburn, G.D. (1981) Progesterone binding protein in bovine corpus luteum. J. Steroid Biochem. 14, 841-850.

Willcox, D.L., Parry, D.M. \& Morris, J.F. (1983) Storage of progesterone in secretory granules. Spec. Sci. Techn. (in press). 